\title{
COVID-19 in Sri Lanka and Seven HRM Related Recommendations against COVID-19
}

\section{H.H.D.P.J. Opatha}

Department of Human Resource Management, University of Sri Jayewardenepura, Sri Lanka. Email:poojaopatha@sjp.ac.lkTel: +94763970842

Abstract

Human resource department that performs Human Resource Management (HRM) function in organizations has to play a key role in fighting against coronavirus while ensuring the sound health and safety of its employees and the sound performance of other HRM functions. A conceptual attempt was done to achieve three research objectives which are, 1) to explore about coronavirus disease and its symptoms, 2) investigate COVID-19 situation in Sri Lanka and, 3) to describe seven HRM related recommendations/strategies that can be adopted by an organization under COVID-19 pandemic situation. A comprehensive literature survey was done to achieve the mentioned study objectives. It was found that coronavirus is an infectious disease caused by a newly discovered coronavirus and its symptoms are fever, cough, fatigue, shortness of breath etc. Sri Lanka is still fighting against COVID-19 with various preventive measures to eradicate the virus from the country and many of those preventive measures have been successful so far. In addition, this study found seven HRM related recommendations that can be adopted by an organization under COVID-19 pandemic situation i.e. invest on training employees for remote working, give more consideration for worker wellbeing, introduce pay cuts instead of layoffs, conduct medical tests at the selection process, create employee resource groups, encourage sick employees to stay at home and, communicate all the necessary actions taken by the organization to employees.

Keywords: Human resource management, Organization, HR department, Coronavirus, Pandemic, Sri Lanka.

JEL Classification: I10 Health: General.

Citation | H.H.D.P.J. Opatha (2020). COVID-19 in Sri Lanka and Seven HRM Related Recommendations against COVID-19. Asian Journal of Social Sciences and Management Studies, 7(2): 152-157. History:

Received: 15 May 2020

Revised: 25 May 2020

Revised: 25 May 2020

Accepted: 2 June 2020

Licensed: This work is licensed under a Creative Commons

Attribution 3.0 License (oc))

Publisher: Asian Online Journal Publishing Group
Funding: This study received no specific financial support

Competing Interests: The author declares that there are no conflicts of interests regarding the publication of this paper.

Transparency: The author confirms that the manuscript is an honest, accurate, and transparent account of the study was reported, that no vital features of the study have been omitted; and that any discrepancies from the study as planned have been explained.

Ethical: This study follows all ethical practices during writing.

\section{Contents}

1. Introduction

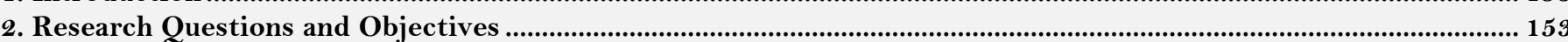

3. Method

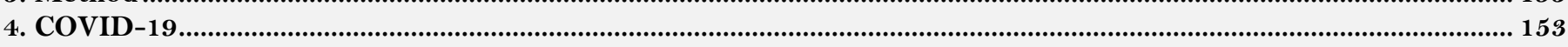

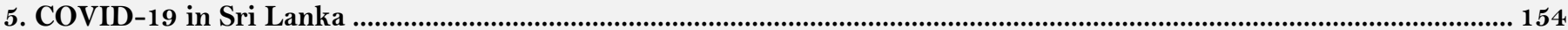

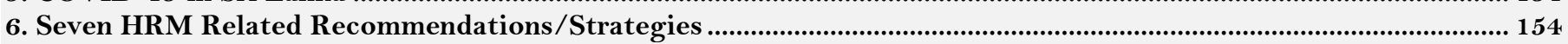

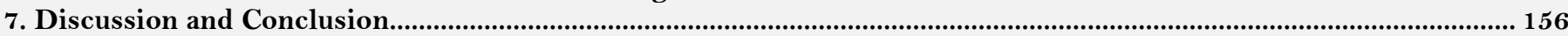

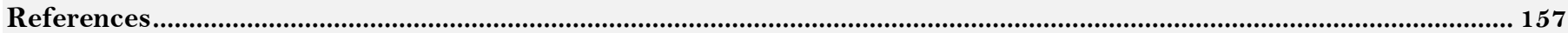




\section{Contribution of this paper to the literature}

This paper mainly attempts to provide some practical recommendations against COVID-19 for organizations from the perspective of HRM and to provide a conceptual contribution to the existing body of knowledge regarding COVID-19 and COVID-19 in Sri Lanka.

\section{Introduction}

Humans make things happen while other resources make things possible (Opatha, 2009). Human Resource Management (HRM) is considered as a critical function among the other organizational functions due to its unique nature as it focusses on managing an exclusive resource which is completely different from other resources (Opatha.. \& Uresha, 2020). According to Opatha (2009) HRM is defined as efficient and effective utilization of human resource in order to achieve organizational objectives and goals. Human resource management is about all aspects of how people are employed and managed in organizations (Armstrong \& Taylor, 2014). Marescaux, De Winne, and Forrier (2019) state that, proper HRM is an antecedent for employees to determine that organization values and cares about their wellbeing, development and contribution. There are various functions being done under HRM (Eg; job design, job analysis, human resource planning, recruitment, selection, hiring, induction, training and development, rewards management, health and safety management etc.).

Due to the pandemic of COVID-19, a greater responsibility rests with HRM to protect its employees' health and safety. Promoting workplace safety and health initiatives is a critical HRM activity (Opatha., 2020) and this criticalness has been increased with the prevailing pandemic situation in the world. Epidemiology Unit: Ministry of Health \& Indigenous Medical Services (2020) in Sri Lanka mentioned that businesses and employers have a major role to play to keep workplaces safe to stop the spread of this disease as workplaces are frequented by a large number of people. Thus, HRM has a great duty to manage the well-being of its workers while performing other HRM functions introducing new strategies in this unprecedented situation. This paper attempts to explore and describe about coronavirus disease, COVID-19 situation in Sri Lanka and seven HRM related recommendations/strategies that can be adopted by an organization to successfully engage in the business process during this pandemic.

\section{Research Questions and Objectives}

Followings are the research questions of this descriptive study:

1. What is coronavirus disease? What are its symptoms?

2. What is the situation of Sri Lanka relating to COVID-19?

3. What are the HRM related recommendations/strategies that can be adopted by an organization under COVID-19 pandemic situation?

Study objectives are to,

1. Explore about coronavirus disease and its symptoms.

2. Investigate COVID-19 situation in Sri Lanka.

3. Present and describe seven HRM related recommendations/strategies that can be adopted by an organization under COVID-19 pandemic situation.

\section{Method}

This study mainly attempts to provide some practical recommendations for organizations from the perspective of HRM and to provide a theoretical contribution to the existing body of knowledge in COVID-19. In order to achieve the three study objectives systematically, a comprehensive literature survey was done by using the desk research strategy in addition to the logical beliefs of the author and observations.

\section{COVID-19}

Corona Virus Disease 2019 (COVID-19) is an infectious disease caused by newly discovered coronavirus (World Health Organization, 2020). This began in Hubei Province, China in December 2019 and now, World Health Organization (WHO) has declared that this virus is a pandemic as it is spreading worldwide. The root cause for the disease is still controversial and unable to say that whether it is a natural or man-made disease. This deadly virus is known as coronavirus, COVID-19, 2019-nCoV acute respiratory disease and novel coronavirus pneumonia. According to Centers for Disease Control and Prevention (2019), most persons with COVID-19 will experience symptoms i.e. fever (83-99\%), cough (59-82\%), fatigue(44-70\%), anorexia (40-84\%), shortness of breath (31-40\%), sputum production (28-33\%), myalgias (11-35\%) and these symptoms will appear within 2-14 days after exposure to the virus. However, there were few cases reported in Sri Lanka to say that some people show symptoms even after 21 days the person is exposed to the virus.

COVID-19 virus is transmitted directly from person to person when a COVID-19 patient coughs or exhales producing droplets that reach the nose, mouth or eyes of another person. At the same time these droplets can land on objects and surfaces surrounding the person and this causes other people who touch those contaminated objects and surfaces and then touch their eyes, nose or mouth, to become infected with COVID-19. Thus, WHO has recommended all the people living in the world to maintain at least one meter distance between two persons, when associating general public. Further, World Health Organization (2020) recommends that everyone should perform hand hygiene frequently and avoid people with fever or respiratory symptoms in order to limit coronavirus transmission. As per Epidemiology Unit: Ministry of Health \& Indigenous Medical Services (2020) in Sri Lanka, most persons who are infected by coronavirus develop mild symptoms and recover without any complications while those with low immunity and people suffering from conditions such as diabetes, heart, liver, lung disease and people who are older than 40 are more at risk.

COVID-19 pandemic has caused 377,607 deaths and 6,374,287 are infected all around the world while 2,909,749 are cured (worldometer, up to date 02/06/2020). 


\section{COVID-19 in Sri Lanka}

In Sri Lanka, "COVID-19 Healthcare and Social Security Fund" and "The Presidential Special Task Force" have been established to effectively and efficiently regulate and control the spreading virus (Silva, 2020). Sri Lanka is the first country in South Asia, that imposed a nationwide weekend curfew (Silva, 2020) to avoid spreading this deadly coronavirus throughout the country. The villages where coronavirus positive patients were identified were locked down until no coronavirus positive patient is found from the same village. Foods and other necessary goods were distributed under safety measures among the people living in COVID-19 high-risk areas in the country by commercial vans and lorries during the curfew and locked down periods. Nearly 45 quarantine centers have been built in the country and foreigners, local people coming from abroad and doubtable persons who have closely associated coronavirus positive patients are sent to those quarantine centers for two weeks and conduct PCR (Polymerase Chain Reaction) test for them. Another strategy that Sri Lankan government is adopting to reduce the crowd in the outside environment is allowing the general public to leave their houses according to the last number of their national identity card ( 1 and 2 - Monday, 3 and 4 - Tuesday, 5 and 6 - Wednesday, 7 and 8 - Thursday, 9 and $0-$ Friday). People who are going for jobs can use their workplace ID, national ID card or e-mail messages sent by the organizations informing its employees to come to the workplaces, as their travelling passes.

State intelligence service of Sri Lanka, Sri Lanka armed forces, police, public health inspectors and Sri Lankan health sector are working hard continuously tackling with coronavirus to destroy it from the country. In addition, the media channels, some reputed and non-reputed organizations, farmers etc. of Sri Lanka are doing a great job by providing needy things to the poor people, temples, churches and other divine places around the country as CSR (Corporate Social Responsibility) activities. In some places of the country, it is observed that Sri Lankan army officers and police officers did not forget to supply foods for innocent animals like cats and dogs walking around the locked down cities.

In Sri Lanka there are 1643 coronavirus cases and 11 deaths while 811 are recovered (COVID-19 alert: Sri Lanka, up to date 02/06/2020). 31 clusters of infections have been reported so far (up to date 02/06/2020) and almost all of them are under control of Presidential Special Task Force. Figure 1 shows how coronavirus cases have been reported daily up to 01/06/2020 from the date (11/03/2020) the first coronavirus infected patient was identified. The graph shows that COVID-19 infected people in Sri Lanka are not continuously increasing daily but there are increasing cases and also decreasing cases. The reason for this may be the right preventive measures taken by the Sri Lankan government. The highest number of coronavirus infected persons for a day was reported as 150 on $28^{\text {th }}$ of May due to COVID-19 infected Kuwait returnees (local labors).

Silva (2020) mentioned that Sri Lankan government has given their due consideration toward managing of public crowds and wearing of protective masks, providing most essential facilities to the victims at the right time, expanding the threshold of health sector, preventing poor communities being hurt from a possible economic epidemic (Eg; Rs. 5,000 were given twice for poor people and income losers through village officers of Sri Lanka).

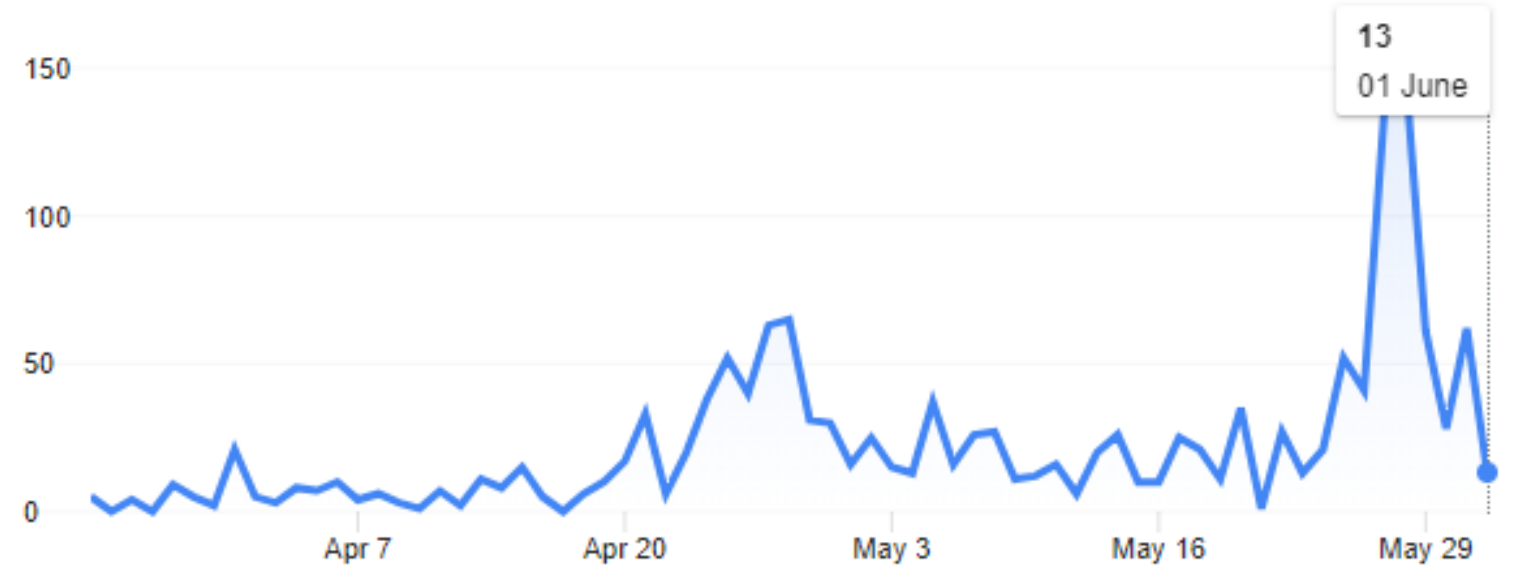

Figure-1. Coronavirus Cases in Sri Lanka.

Source: Wikipedia (COVID-19 alert; Sri Lanka) up to date 01/06/2020.

\section{Seven HRM Related Recommendations/Strategies}

\subsection{Invest on Training Employees for Remote Working (Training and Development)}

Companies all around the world encourage or motivate employees to work from home during the corona virus pandemic. This may be a firsthand experience for many of the employees in the world, especially for employees in developing countries like Sri Lanka.

Meister (2020) has examined various ways the companies are dealing with remote working and one way is training employees to work from home. She has identified that many organizations in USA provide training for employees on working remotely, working remotely while in quarantine and also training managers to manage remote workforce successfully. Microsoft has created a Guide to Working from Home During COVID-19 and this guide was shared with the Microsoft global workforce (Meister, 2020). For their customers, a version of that was made as an editable document to use with their own organizational conditions (Meister, 2020).

It is recommended for organizations to use online or cloud platforms where their employees can work remotely, learn new competencies, ask questions from their supervisors and colleagues, share opinions and ideas etc. while being healthy and productive. As an additional advantage of working from home, it makes employees to maintain a proper balance between their work life and family life.

\subsection{Give More Consideration for Worker Wellbeing (Health and Safety Management)}

Due to the fact that this deadly COVID-19 virus is spreading all over the world, one of the major considerations or might be the first priority in the organization is well-being of the workers. If one of the 
employees gets infected with this deadly virus, it surely can be a cause to shut down the whole organization at an instant. Therefore, HRM needs to take relevant initiatives to protect worker well-being. Meister (2020) said that "Today more than ever, the future of work is the future of worker wellbeing".

Thus, every employee of the organization must be informed to practice good safety practices while maintaining social distance to protect others as well as themselves. For those employees who do not work according to the safety practices of the organization can be punished through disciplinary actions. Construction Industry Development Authority (2020) has mentioned health and safety guidelines for employees in construction industry to be adopted during COVID-19 and some of them are given below as an example.

- $\quad$ All workers must wash hands with soap or hand sanitizer containing alcohol and running water when entering the construction site.

- Workers shall refrain from spitting or sneezing/coughing, putting out the discharge of phlegm in public places.

- In extreme situations where the standard of protective mask is a requisite, a particulate respirator at least as protective as a NIOSH certified N95, EU standard FFP2, or equivalent shall be used.

- Employer shall appoint a Health and Safety Committee for every work site, with representations from the Contractor. The said committee shall be convened at least once a week and discuss with the workers about the current status of the epidemic, situation in the construction site and potential threats and decisions have to be taken providing solutions.

- If by any chance, it is known that one or more workers in the work site is infected with COVID-19, he shall be at once sent to a specified government hospital by an ambulance.

- $\quad$ The details of the other workers who closely worked or associated with the infected person shall immediately be notified to the nearest Hospital or to Special Units appointed by the Health Ministry / President's Task Force.

Likewise, organizations in other industries also should follow comprehensive health and safety guidelines as mentioned above and HR must take the first step of initiating them. Other than the above practices organizations have to rethink on some areas like conducting meetings, using elevators, sanitary facilities, using lunch rooms and changing rooms, transport facilities, accommodation etc. in order to ensure the safety of every human being. Further, organizations have to take steps to keep their organizations extra clean to avoid spreading of virus. It is compulsory for every organization to check the temperature of employees using temperature test machines when they are entering into the organizational premises. Another safety initiative is that organization can introduce a transport facility system if they have the possibility, to let the employees travel from their home to workplace and from workplace to home. This will reduce the chance of employees getting exposed to the external public in public transportation vehicles (Eg; bus, train) and simultaneously reduce the probability of getting infected by COVID-19 virus.

It is not only about the physical health of the employees but also about the mental health of the employees. According to Opatha. (2020) there are 15 fears for employee due to COVID-19 and they are fear of getting affected by himself or herself, fear of possibility of getting quarantine, fear of getting stigmatized by the public and friends, fear of getting affected by his or her closely loved ones, fear of getting affected by others, fear of becoming a cause of spreading the epidemic, fear of attending the work, fear of getting sanction/s, fear of peer pressure, fear of harsh customer response, fear of losing the job, fear of continuity of business operations, fear of inability of implementing plans developed, fear of inability of formulating new plans for better future, and fear of loss of pursuits of pleasure. Opatha. (2020) has mentioned that the employee will get one or two or several or all types of fears mentioned above and as a result of that he or she becomes stressful. This type of stress is labeled as Stress By Corona (SBC) (Opatha., 2020). Thus, it is a responsibility of HR department to make preventive actions from the organization's side to diminish or eradicate those fears through counselling and executing standard health and safety practices as mentioned before in the paper. Ultimately this will minimize employees' Stress By Corona (SBC).

\subsection{Pay Cuts Instead of Layoffs (Pay Management)}

One of the major challenges for organizations during this pandemic is to pay salaries for employees. Paying salaries as usual might not be possible for many organizations as they were shut down at least for a month in many countries. In Sri Lanka many of the private and public organizations were closed for nearly two to three months and still there are some barriers to open some business organizations due to the prevailing quarantine curfew in some areas of the country at the moment. As a result of this organizations couldn't earn profits as usual and now, they are struggling with paying salaries to the employees. Hence, some organizations have started to layoff employees. This has also become a cause for many employees' mental stress as they are losing their income source. But it is more suitable for HR to help the company and the employees of the organization during this hard time, by proposing salary cuts for a predetermined period instead of layoffs (Jaisinghani, 2020). Here, proper communication must be held between the HR department and trade union/s of the organization. For an example, one HR Manager of an organization in Sri Lanka mentioned that they have requested all the Senior Managers and above staff to salary deferment on voluntary basis from April onwards. They have given options to cut their salaries as a percentage of $0 \%, 20 \%, 40 \%, 50 \%$ from the basic salary. Further, he mentioned that Senior Managers individually responded to the HR department and this strategy helped their company to save money in millions to manage lower staff salaries. Another example is management can reduce salaries up to $25 \%$ for a period of 6 months so that the company can survive and no staff needs to be laid off (Jaisinghani, 2020).

\subsection{Conduct Medical Tests at the Selection Process (Employee Selection)}

When selecting a job candidate for a vacant job it is necessary to conduct some tests to find the most appropriate and qualified person for the job. In a selection process first, applications are screened and then selected applicants are called for interviews. Further, different types of tests like personality tests, aptitude tests, background investigations and medical tests are done. It was not compulsory for many organizations to conduct medical tests when selecting employees to the organizations so far. However, from now onwards it may become an integral task to conduct medical tests to make sure that newly selected job candidate is not a COVID-19 positive 
patient who has the possibility of making a significant negative impact to the organization and its employees in future. PCR (Polymerase Chain Reaction) test or other health measuring tests have to be implemented by the organizations in future when selecting employees.

\subsection{Create Employee Resource Groups (Job Design)}

One of the HR functions in an organization is job designing which means arranging duties, tasks, responsibilities in to an organizational unit of work to achieve organizational objectives (Opatha, 2009). As a solution for COVID-19 pandemic situation HR can form a group called Employee Resource Group (ERG) under group technique of job designing. Under the supervision of HR department of the organization this team can be formed. The major objective of forming an ERG is to provide support for other employees in terms of various aspects relating to work.

Through these employee resource groups, organization can successfully provide work support for other employees to work remotely, enhance career development through online learning facilities and mentoring, enhance worker happiness of employees on the job and, solve employee grievances relating to unnecessary pay cuts, terminations, layoffs etc. Organizations must promote online virtual conversation platforms to contact employee resource groups by the other employees of the organization. A proper training needs to be given for employees in the resource team in order to provide a quality service to other employees of the organization and training those employees is a responsibility of HRM.

\subsection{Encourage Sick Employees to Stay at Home (Presenteeism Management)}

This is very much important for the organization to not to ask employees come to work while they are ill or if they show the symptoms of coronavirus (fever, cough, sore throat, and shortness of breath etc.). This attempt will ensure that other employees in the organization are not in a risk of being infected by corona and also avoid presenteeism which means that employees come to work while they are ill and do not work productively. If the organization has the possibility, they can provide insurance facilities for their employees or corona infected employees to cover their medical expenses as a welfare facility under HRM and this might increase employer branding of the organization.

\subsection{Communicate All the Necessary Actions Taken by the Organization to Employees}

Taking necessary actions by the HR people and other managers of the organization to fight against COVID-19 is not enough, but also need to communicate those actions to employees in an understandable way because ultimately these actions are executed by employees in the organization. Therefore, it is recommended to send an email to all the employees who have e-mail facilities, informing safety measures or share newly introduced safety policies and other related policies and procedures via social media. Those e-mail or online facilities might not be available for some poor factory workers living in some developing countries like Sri Lanka. However, they can be communicated through word of mouth method or displaying posters and notices in the places where they regularly attend (Eg; lunch room, bathroom area, inside the factory, rest rooms etc.) in the organization.

Figure 2 depicts the above seven HRM related recommendations.

\section{Discussion and Conclusion}

Coronavirus disease 2019 is a newly identified infectious disease which spreads primarily through droplets of saliva or respiratory droplets discharge from the nose and it is deadly and very expensive humanly and financially (Opatha., 2020). It is very much important to keep the social distance and maintain hygienic practices to clean our hands and other body parts in order to limit the viral transmission of the virus.

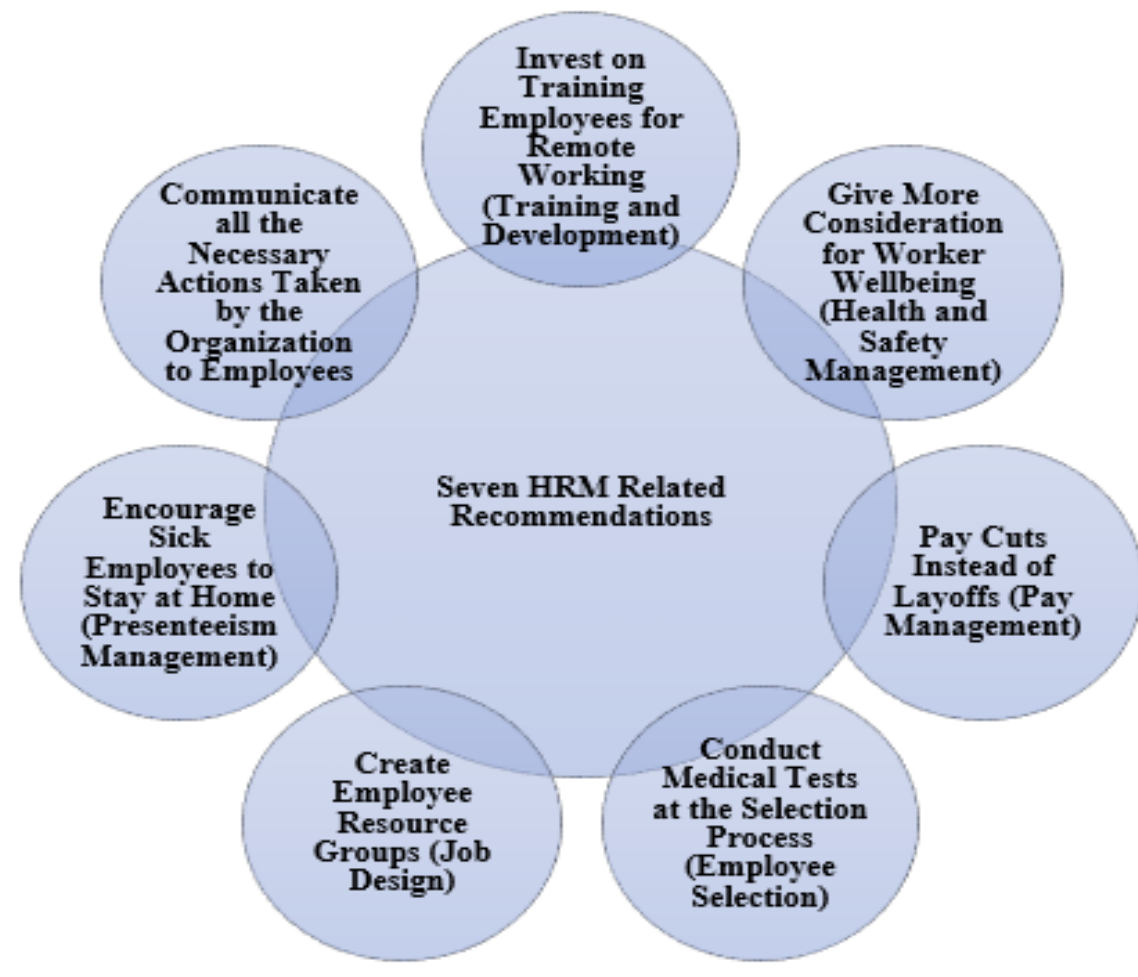

Figure-2. Seven HRM Related recommendations. 
According to Gamage (2020) Sri Lanka is considered as a model for the world as most of the health indicators have been improved tremendously despite the low resource setting. State intelligence service of Sri Lanka, Sri Lanka armed forces, police, public health inspectors and Sri Lankan health sector are doing a great job against coronavirus pandemic. Coronavirus has also infected the normal business process of organizations where HRM is responsible for managing employees efficiently and effectively. HRM has to play a major role in this unprecedented situation to ensure the worker well-being and sound performance of HRM functions (Eg; selection, training and development, pay management, performance evaluation etc.). Therefore, It is recommended to invest more on training employees for remote working, give more consideration for worker wellbeing, introduce pay cuts instead of layoffs, conduct medical tests at the selection process, create employee resource groups, encourage sick employees to stay at home and, communicate all the necessary actions taken by the organization to employees for a successful implementation of HRM during COVID-19 pandemic.

\section{References}

Armstrong, M., \& Taylor, S. (2014). Armstrong's hand book of human resource management practice. London: Kogan Page Limited.

Centers for Disease Control and Prevention. (2019). Coronavirus disease 2019 (COVID-19): Symptoms. Retrieved from: https://www.cdc.gov/coronavirus/2019-ncov/symptoms-testing/symptoms.html, Accessed on 04/05/2020.

Construction Industry Development Authority. (2020). Health and safety guidelines for Sri Lankan construction sites to be adopted during COVID 19 outbreak. Retrieved from http://www.cida.gov.lk/index_new.html. [Accessed02/06/2020].

Epidemiology Unit: Ministry of Health \& Indigenous Medical Services. (2020). Guidance for workplace preparedness for COVID-19. Retrieved from: https://epid.gov.lk/web/. [Accessed 02/06/2020].

Gamage, A. (2020). Is Sri Lanka prepared to tackle the coronavirus?, Lakshman Kadirgamar Institute of International Relations and Strategic Studies, Rereieved from: https://www.lki.lk/blog/is-sri-lanka-prepared-to-tackle-the-coronavirus/, Accessed on $04 / 05 / 2020$

Jaisinghani, A. (2020). Pandemics \& HR in 2020: The impact of COVID-19 on the workforce, Retrieved from: https://www.peoplemattersglobal.com/blog/employee-relations/pandemics-hr-in-2020-the-impact-of-covid-19-on-the-workforce25289. [Accessed 02/06/2020].

Marescaux, E., De Winne, S., \& Forrier, A. (2019). Developmental HRM, employee well-being and performance: The moderating role of developing leadership. European Management Review, 16(2), 317-331.Available at: https://doi.org/10.1111/emre.12168.

Meister, J. (2020). The impact of the coronavirus on HR and the new normal of work - Forbes, Retrieved from: https://www.google.com/amp/s/www.forbes.com/sites/jeannemeister/2020/03/31/the-impact-of-the-coronavirus-on-hr-andthe-new-normal-of-work/amp/. [Accessed on 04/05/2020].

Opatha, H. H. D. N. P. (2009). Human resource management: Personnel. Sri Lanka: Author.

Opatha., H. H. D. N. P. (2020). The coronavirus and the employees: A study from the point of human resource management. Sri Lankan Journal of Human Resource Management, 10(1), 37-49.

Opatha.., H. H. D. P. J., \& Uresha, K. I. (2020). HRM and its impact on employee happiness: An empirical study on Sri Lankan employees. Asian Journal of Social Sciences and Management Studies, 7(2), 114-123.

Silva, D. A. C. S. (2020). Sri Lanka: Victory against the COVID 19: Get ready for hardworking to make the country better. Retrieved from https://www.researchgate.net/publication/340570606_Sri_Lanka_Victory_Against_the_COVID_19_Get_Ready_for_Hardworki ng_to_Make_the_Country_Better. [Accessed 02/06/2020].

World Health Organization. (2020). Coronavirus disease 2019 (COVID-19) situation report - 66 (Data as reported by national authorities by 10:00 CET 26 March 2020). from: https://webcache.googleusercontent.com/search?q=cache:mhRPrsNmSowJ:https:// www.who.int/docs/defaultsource/coronaviru se/situation-reports/20200326-sitrep-66-covid-19.pdf\%3Fsfvrsn\%3D9e5b8b48 2+\&cd=1\&hl=en\&ct=clnk\&gl=lk. [Accessed 02/06/2020]. 